\title{
Solar Home Systems as the Basis for Bottom-Up Grids
}

\author{
${ }^{* 1}$ S. P. Jolhe, ${ }^{2}$ Dr. G. A. Dhomane, ${ }^{3}$ M. D. Karalkar. \\ ${ }^{*}$ Government College of Engineering, Nagpur \\ ${ }^{2}$ Government College of Engineering, Chandrapur \\ ${ }^{3}$ Priyadarshini J. L. College of Engineering, Nagpur \\ *Email: sp.jolhe@gov.in
}

Received: $17^{\text {th }}$ January 2019, Accepted: $13^{\text {th }}$ February 2019, Published: $3^{\text {th }}$ June $^{2019}$

\begin{abstract}
People living in India's rural areas still have no access to electricity. According to the ministry of new and renewable energy (MNRE); this count is more than 400 million people (47.5\%). While there are still more than 2.3 billion people in the world without reliable access to electricity. Due to remoteness of these places; it is not possible to give the supply from the central grid. Many area are hilly or forest or deep forest. It is not feasible as well as economical to lay the lines in such areas. The environment constraint of polluted air and water are on the verge of explosion. To avoid all the mentioned constrain the renewable energy sources are the most appropriate. These sources are environmental friendly as well as easy to erect. This paper present the DC operated system model for standalone application with and without battery. The analysis has been made for excess energy produced by solar PV system.
\end{abstract}

Keywords

Bottom up, DC Bus System, Solar PV System

\section{Introduction}

Since year 2013, India became the world's third largest producer of electricity, surpassing Japan and Russia, with 7.4\% global share in electricity generation (BP Statistical Review, 2016). As on 31.10.2018; India had an installed capacity of $346.048 \mathrm{GW}$ (Power sector at glance, Ministry of power).

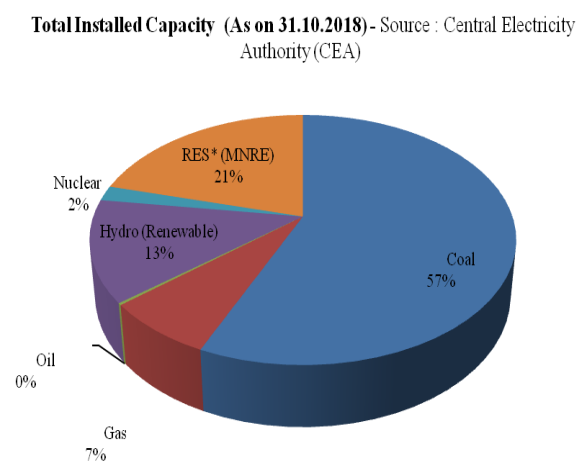

Figure 1: Indian Scenario of Power Generation

Among this total installed capacity, Renewable Power plants constituted 20.8\% (Ministry of New and Renewable Energy- MNRE) and 13.1\% contribution from hydro (Renewable); total contribution of renewable energy is $33.9 \%$ i.e. one third of the total electric power generation in India

Non-Renewable Power Plants constituted the remaining 66.1\%. Coal operated power plant are still contributing the highest electric power generation $195.993 \mathrm{GW}(56.6 \%)$ and gas contribute $7.2 \%$, oil contribution is $0.2 \%$ During the financial year 2017-18; the gross electricity generated by utilities is 1,303 TWh and 183 TWh by captive power plants. Auxiliary power consumption of the power generation plants is also included in gross electricity generation (Growth of Electricity Sector in India from 1947 -2015. CEA, India. 2018). Figure 1 shows the power generation scenario in India.

Although so huge generation of electric power, still power companies are not able to fulfill the requirements of the people. Fig 2 shows the power supply position in India, which clearly indicates that the power is short. 


\section{Power Supply Position}

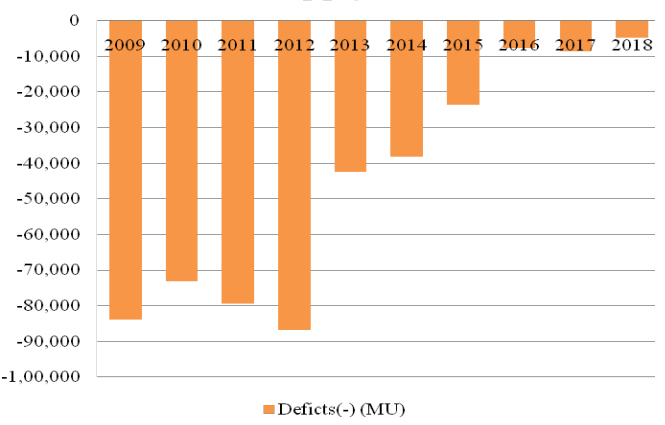

Figure 2: Indian Power Supply Position

According MNRE; people living in India's rural areas still have no access to electricity. This count is more than 400 million people, about 47.5\% (Ministry of New and Renewable Energy- MNRE). While there are still more than 2.3 billion people in the world without reliable access to electricity to them (United Nations Foundation2012) Because of the remoteness of these places it is not possible to supply electricity from the central grid. Many areas are hilly or forest or deep forest. It is not feasible as well as economical to lay the lines. Due to huge, tall trees \& bamboo bushes the breakdown occurs frequently on electrical lines causing interruptions in supply of electricity. To provide the electricity to all with conventional plant is not economical and feasible. The environment constraint of polluted air and water are on the verge of explosion. To avoid all the mentioned constrain the renewable energy sources are the most appropriate. These sources are environmental friendly as well as easy to erect.

"Power for All", scheme launched by Government of India for supplying electric power supply to all the people in the country by March 2019 (Power for All). With this scheme India will find the unexplored electrical power available in the country. One of the ways is Solar Home System (SHS).

\section{Solar Home System (SHS)}

According to the Indian climate, most relevant renewable, affordable and low maintenance source is solar PV system. A photovoltaic system is made up of several photovoltaic solar cells. A single PV cell can generate very small power about 1 or $2 \mathrm{~W}$, depending upon material and type of construction. For higher power output, different connection combinations of PV cells are used like series, parallel and series parallel.

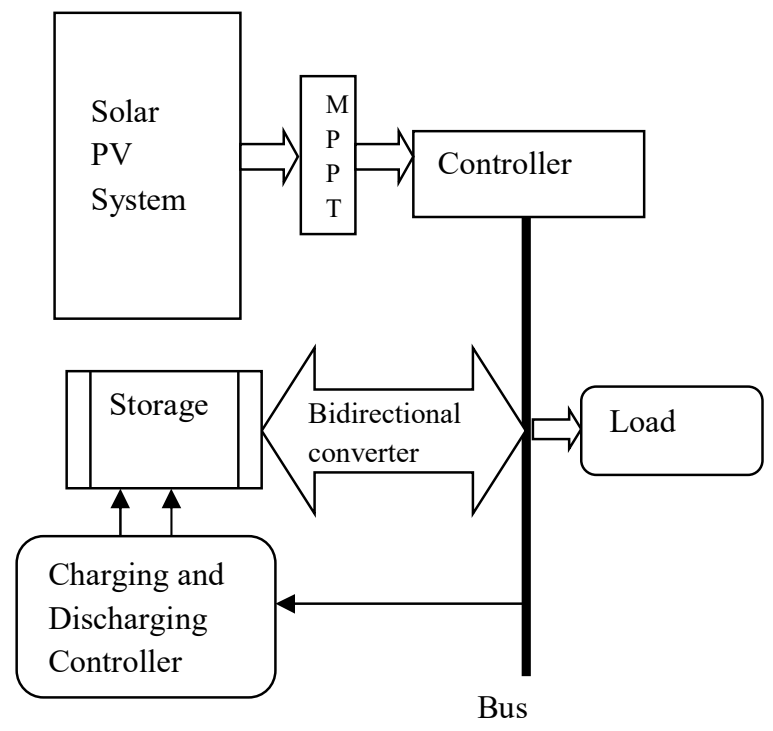

Figure 3: Solar Home System (SHS)

Solar PV systems performance is based on the efficiency or the performance of the individual components. Apart from the solar PV module the system components comprises a battery charge controller, an inverter, MPPT controller and some of the low voltage switchgear components. 
Fig 3 shows the schematic diagram of the Solar Home System. In this, solar PV panel is generating the power with suitable MPPT for maximum power to be generated. This power is then given to converter. According to the system requirements; converters are classified in two types:

a) $\mathrm{DC}$ to $\mathrm{AC}$ converter for $\mathrm{AC}$ power system.

b) DC to Dc converter for DC power system.

In this paper only DC power system is consider because of its advantages. This power is then supplied to the load directly. According to load requirement, power will be taken from the supply. Normally battery is connected to store the excess electricity for further use, when no solar power is available i.e. during night time. To store power in the battery bidirectional converter is required. It will be in used during charging of battery and in discharging of battery. To protect battery from excess charging and discharging one more unit is required "Charging Discharging Controller". Some protection equipment are also used which are not shown here.

As the generation is DC and stochastic in nature controller is need to control and for proper supply. This gives the other option for the system that it can operate on the different frequency or on DC grid system (S.P. Jolhe et al., 2016)

Following are the options

1. DC power supply

a) High voltage DC (HVDC)

b) Low Voltage DC (LVDC)

2. AC Power supply

a) $162 / 3 \mathrm{~Hz}$

b) $50 \mathrm{~Hz}$

c) $400-500 \mathrm{~Hz}$

d) $20 \mathrm{KHz}$

Out of all these options available for transmission of electric power, only conventional $50 \mathrm{~Hz} \mathrm{AC}$ power and DC supply with low voltage is more economical and suitable for solar home system (SHS).

Electricity demand of the majority of the rural households is basic lighting load, mobile charger load, fan load, television and radio. Irrigation, Dal mill, rice husking etc. are agriculture load and require large electric power. A small solar PV cell unit can provide electric power to these basic demands. The people from the rural areas are also now interested in getting electric power supply at their home to have convenience like light, fan, colour television and also keen for the agriculture harvesting through irrigation, preserving the food and agriculture products also. This is reported by different agencies (Mahmud Ibrahim et 2016) It is also reported that people are ready to pay for $t$. he electricity used. DC system can be used for such loads.

DC system has the following advantages over AC system

- All modern electric load can fully functional on AC and DC power supply such as CFL/ LED Light, Television, etc

- Fan, Pumps and other electrical motor can operate on the DC power supply with higher efficiency.

- No inverter is required as solar output is also DC

- Storage device is normally battery, which also operates on DC, so no converter is required. As well as $110 \mathrm{~V}$ to $220 \mathrm{~V}$ DC can transmit power up to few hundred meters

- Losses are very low in DC transmission

- No problem of power factor

- Inter connection of system is easy than AC power supply

- New addition in parallel is much easier in DC

- Less harmonics problem

\section{Batteries in PV Systems}

Battery plays an important role in the PV solar system. Many factors are affecting the selecting suitable battery for a PV application. The election of the specific battery for the specific application is mainly depends on physical properties, while other decisions will be much more difficult and may involve making trade-offs between desirable and undesirable battery features.

In battery subsystem design many consideration are included like:

- How many batteries should be connected in series/ parallel or any series parallel combination?

- What should be over-current setting?

- Setting requirement in overcharging or over drained?

- What should be disconnecting requirements?

- Selection of the proper wire sizes and types.

Deepening upon the requirements of the system the energy output from the Solar PV systems is stored in a battery or in a battery bank. Generally batteries are the first choice in stand -alone system for the storage and in grids connected PV system batteries are used as a backup system. The primary functions of the battery in a PV system are (S. Sumathi, et, al 2015) 
i. Storage: when PV array is producing electrical energy, it should be store

ii. Supply energy on demand: Whenever needed by the consumer the electrical energy should be available to electrical loads

iii. Quality of supply: stable voltages and currents should be supplied to electrical loads, by suppressing or 'smoothing out' transients.

iv. Supply high peak operating currents : If needed by electrical loads or appliances, battery should provide /supply the high peak operating currents or surge

\section{Simulation Model}

The simulation model consists of a $60 \mathrm{Wp}$ solar panel and a 100 Ah battery. The model is for the solar system for home which forms the nanogrid. Details of the respective component modelling are as follows.

\begin{tabular}{|l|l|l|}
\hline S No & Parameter at Standard Test Conditions & Value \\
\hline 1 & Maximum number of cell & 36 \\
\hline 2 & Maximum Power Pmax & $60 \mathrm{~W}$ \\
\hline 3 & Voltage at Pmax & $17.1 \mathrm{~V}$ \\
\hline 4 & Current at Pmax & $3.5 \mathrm{~A}$ \\
\hline 5 & Open Circuit Voltage Voc & $21.1 \mathrm{~V}$ \\
\hline 6 & Short Circuit Current Isc Model Parameter (Defined) & $3.8 \mathrm{~A}$ \\
\hline 7 & Temperature Coefficient of Voc & $-0.38 \% /{ }^{\circ} \mathrm{C}$ \\
\hline 8 & Temperature Coefficient of Isc & $0.065 \% /{ }^{\circ} \mathrm{C}$ \\
\hline \multicolumn{2}{|l|}{} \\
\hline 1 & Band energy Eg & $1.12 \mathrm{eV}$ \\
\hline 2 & Ideality factor A & 1.2 \\
\hline 3 & Shunt resistance Rsh & $1000 \mathrm{ohm}$ \\
\hline 4 & Coefficient Ks & 0 \\
\hline \multicolumn{2}{|l}{} \\
\hline 1 & Series resistance Rs & $0.008 \mathrm{ohm}$ \\
\hline 2 & Short circuit current Isc0 & $3.8 \mathrm{~A}$ \\
\hline 3 & Saturation current Is0 & $2.16 \mathrm{e}-8 \mathrm{~A}$ \\
\hline 4 & Temperature coefficient Ct & $0.0024 \mathrm{~A} / \mathrm{K}$ \\
\hline
\end{tabular}

Table 1: Parameters Used in the PV Module Model

\section{Simulation Model Without battery}

The model consists of the $60 \mathrm{Wp}$ solar panel The test condition is taken as a standard test condition (STC). The resistive load is considered only. The load is increased in three steps of $20 \mathrm{~W}$ each and system response is studied. Initially for very small timing non-considerable load is connected to the grid for small tine, then no load on the grid up to $t=0.3$, The load of $20 \mathrm{~W}$ is connected to the grid system up to $t=0.6$, a $20 \mathrm{~W}$ load is added at $\mathrm{t}=0.6$ and process is repeated at $\mathrm{t}=0.8$. The total load on the system is $60 \mathrm{~W}$, which is maximum capacity of the system.

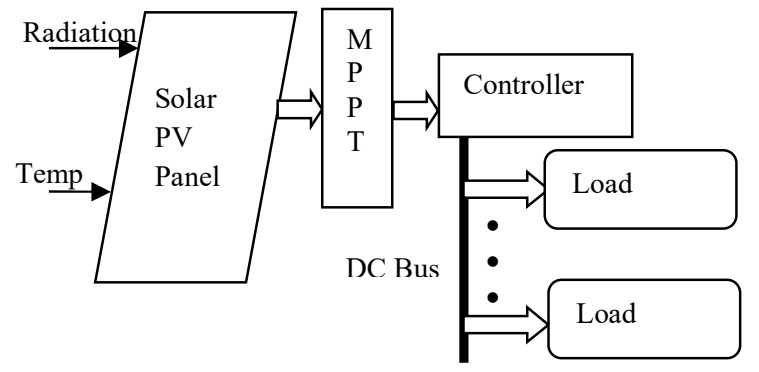

Figure 4: Solar Home System (SHS) Model Without Battery 


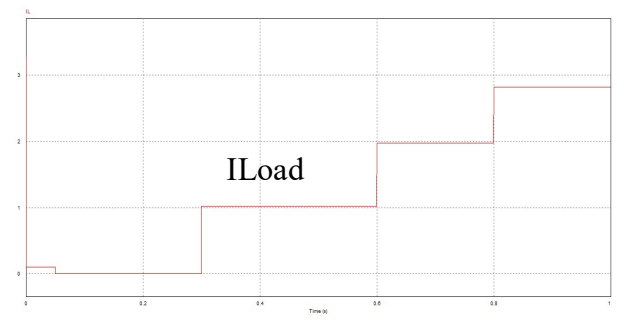

a

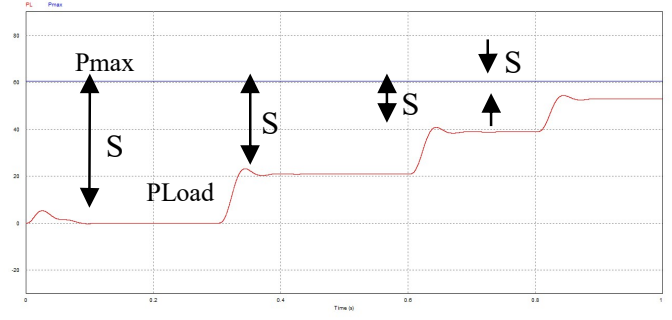

b

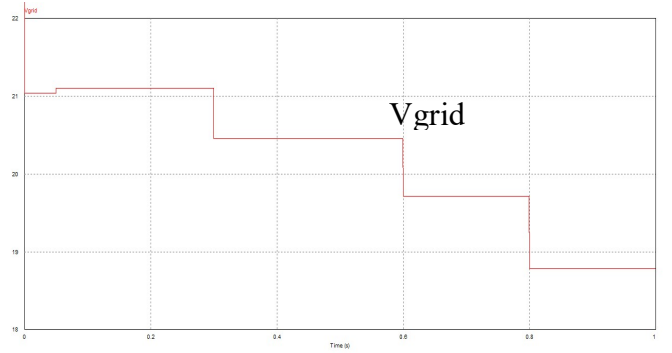

$\mathrm{c}$

Figure 5: Simulation Results a) Load Current Variation from Minimum to Maximum Load; b) Power Variation from Minimum to Maximum Load and Maximum Power Generated by the Solar Pannel c) Voltage Variation from Minimum to Maximum Load

Fig 5 (a) shows the variation of the load current with increasing load from minimum to maximum. Maximum load current for the circuit is 2.8A. This is due to voltage regulation. Fig 5(c) shows variation of the load voltage from minimum to maximum load. The load voltage in starting load is $20.45 \mathrm{~V}$ and for end load is $18.78 \mathrm{~V}$.

$\%$ Voltage Regulation $=[(21.1-18.78) / 21.1] * 100=10.99 \%$

Fig 5 (b) shows the variation of the load power with the load from minimum to maximum. Although the connected load is $60 \mathrm{~W}$, but the simulation results shows it is little less than maximum $60 \mathrm{~W}$. This is due to the voltage regulation. In this circuit voltage regulation is very high, $11 \%$ ( approximately). The load voltage decreases from $21.1 \mathrm{~V}$ to $18.70 \mathrm{~V}$.

In the circuit, initially as it is assumed that only $2.2 \mathrm{~W}$ load is connected, then no-load condition occurs at $\mathrm{t}=0.05$ and further the load is going to add after interval, after $\mathrm{t}=0.3, \mathrm{t}=0.6$ and $\mathrm{t}=0.8$.

During no-load duration, S1 is the power generation and utilization difference, as shown in fig 5(b). As the load increases this difference is going to reduce. This is pure loss of generation. Normally during the load is very low or no-load condition occurs on many time. The requirement of power is in the off sun period or in our case off generation period. If battery is connected, the excess generation can be utilized and power can be used at off generation period.

It is very much difficult that load curve is following the generation curve. Typical generation by solar PV cell is during day time and electricity requirement is in night for household purpose. Without battery Solar PV cell system will usually used in irrigation.

Simulation Model With Battery

The circuit consists of the same load and Solar PV panel as consider above. 


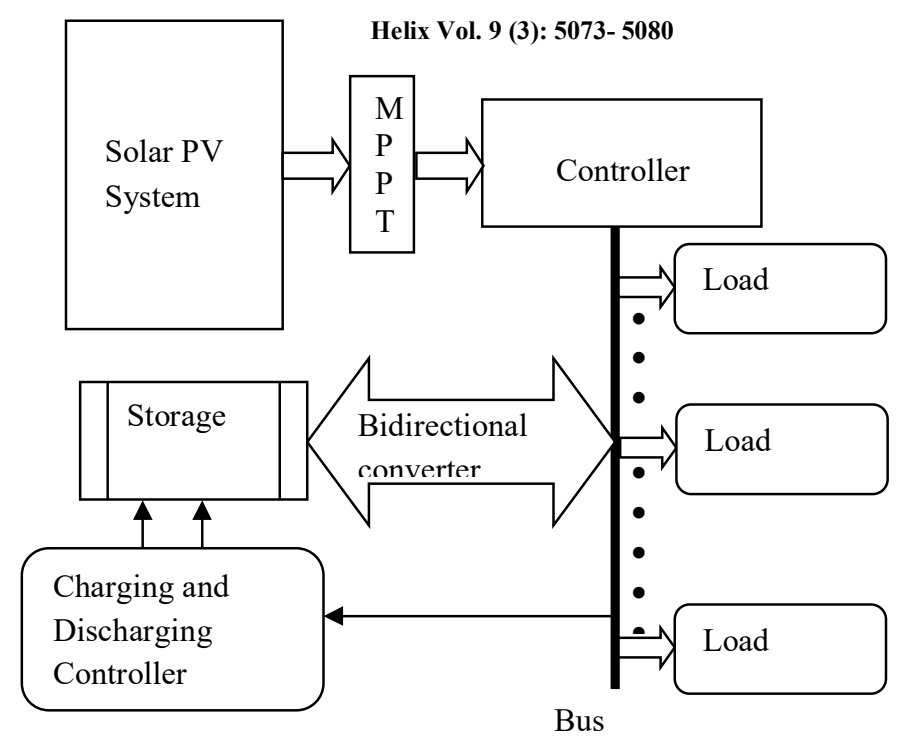

Figure 6: Solar Home System (SHS) Model With Battery

Now standard test condition are not consider, the variation of the isolation is from $0 \mathrm{~W} / \mathrm{m}^{2}$ to $1000 \mathrm{~W} / \mathrm{m}^{2}$, as well as the temperature perturbation is taken into consideration from $15^{\circ} \mathrm{C}$ to $45^{\circ} \mathrm{C}$. This variation in isolation and temperature is taken in consideration so as to get the real time variation and experience. Addition of the battery with charge control circuit is made to store the excess amount of power generated during the day time and can easily be utilized at night/ whenever needed.

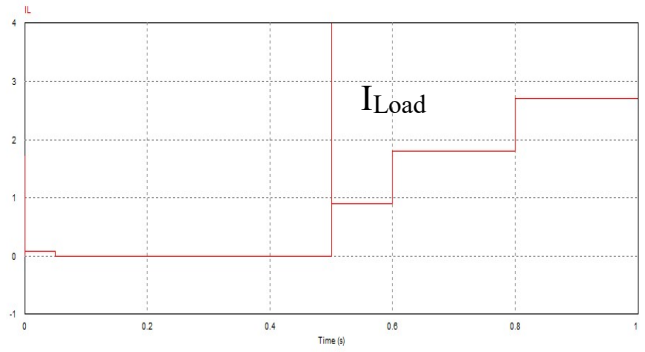

a

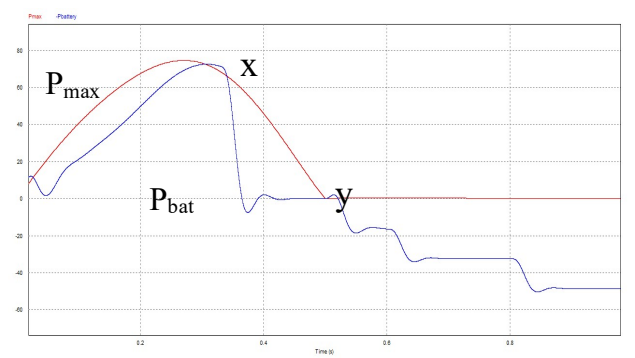

b

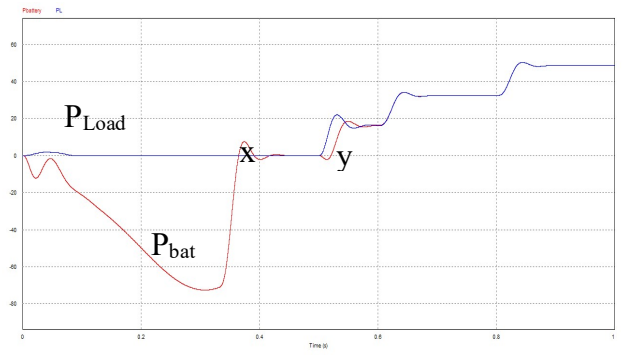

c 


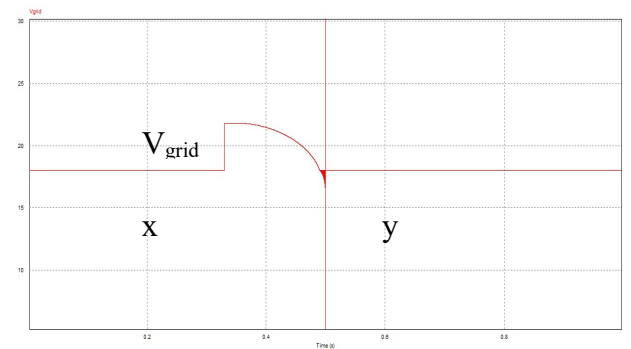

d

Figure 7: Simulation Results for Battery Connected System a) Load Current Perturbation from Minimum to Maximum Load; b) Maximum Power Generated by the Solar Panel and Load Power minus Power taken by Battery c) Load Power Perturbation from Minimum to Maximum Load and Power taken by Battery d) Voltage Perturbation from Minimum to Maximum Load

Figure 7(a) shows load current perturbation from minimum load to maximum load. Initially very small load is connected to the system up to $t=0.05$. The load is removed or no load condition occurs from $t=0.05$ to 0.5 . The load of $20 \mathrm{w}$ is connected at $\mathrm{t}=0.5$, this creates the transient of $16 \mathrm{~A}$ for $1.91 \mathrm{E}-04$ period. At $\mathrm{t}=0.6$ and $\mathrm{t}=0.8$ another load of $20 \mathrm{~W}$ is connected previous load. So at the end $60 \mathrm{~W}$ loads are connected, which is the maximum, capacity of the system. For this system the entire load is supplied by the battery in off generation period.

Figure 7(b) shows is of maximum power generated by the solar panel. As the isolation varies from 0 to 1000 $\mathrm{W} / \mathrm{m}^{2}$, the power generation also varies accordingly. The variation of temperature also assumed to be from 15 to $45^{\circ} \mathrm{C}$. This all have the effect like as actual data. The red curve is for the maximum power generation and blue is the power taken by the battery for charging. As the battery is getting full charged, power taken for charging slowly decreasing to zero. As at $t=0.5 \mathrm{load}$ is switched on. From point $\mathrm{x}$ to point $\mathrm{y}$, the solar power generation is on but as the battery is fully charged and no load is connected during that period, power is wastage. After $\mathrm{t}=$ 0.5 both the curves are showing zero.

As that of Figure 7(b), Figure 7(c), $\mathrm{P}_{\text {Load }}$ and $\mathrm{P}_{\text {bat }}$ is drawn. As the battery is charging it is negative and as the battery is serving power load. Figure 7(d) shows the voltage of the grid. The grid voltage is maintain constant as the solar power generate and battery is charging, at point ' $x$ ', battery get fully charged so battery get disconnected and solar power generation is continuous as well the no load is connected to system, so voltage is nearly equals to no-load voltage. At point ' $y$ ', isolation is zero, so the power generation is zero. The battery is now comes in picture, so transient is occurs.

The voltage of the given circuit is constant and maintain at $18 \mathrm{~V}$. Only for the small instant voltage is of the grid is changed and that is nothing but no-load voltage. System voltage regulation is improved from the above. Because of the noise, load current and grid voltage is showing over shoot in values of current and voltage.

Comparing the above two system following are the advantage of the second system, system with battery, are more than that of other system

a) Reliability of power is more

b) Maximum use of the generated power

c) Improved voltage regulation

d) Improved Power quality

\section{Disadvantages}

a) Cost of system increase

b) Disadvantages of battery like gases, maintenance, space required etc

\section{Discussion and Conclusion}

The simulation results show a high potential of Solar home System (SHS). The excess generation is normally dumped. However if many SHS are connected together to form a smart DC Nanogrid, it will be more advantages. As the system is shared by many people, there will be reduction in unused energy or this excess energy can be used by the community in productive use.

The SHS will give new hope of ray to the people living in off grid areas. It will increase their living standard and enhance socio-economical development.

However, there are many losses like dirt, reflection, shading or losses in the domestic wiring, which have not been taken in consideration but they influence the output and hence efficiency of the system. The load profile assumed plays a critical role. According to the season load variation will be more or less, in paper mill higher impact seasonal load is not considered. Still there is considerable amount of energy available which is not been used. This energy can be generated and sold to grid, which will enhance the economics of the owner. 
The starting of such type of basic of bottom up is SHS. If such SHS are connected together to form Nanogrid will enhance the reliability and ensure more profit. This excess of energy can be used by increasing the battery capacity or giving connection to other household which can store this energy in small batteries.

\section{References}

1. BP Statistical Review of World Energy, June 2016

2. Growth of Electricity Sector in India from 1947 -2015. CEA, India.

3. Mahmud Ibrahim et. 2016. A Smart Solution for Solar DC Nano Grid integrated with Pre-paid billing and Mobile Application. ${ }^{\text {rd }}$ International Conference on Electrical Engineering and Information Communication Technology (ICEEICT).

4. Ministry of new and renewable energy (MNRE) http://mnre.gov.in/schemes/decentralized-systems/

5. Power sector at glance, Ministry of power http://powermin.nic.in/power-sector-glance-all-india

6. Power for All, Ministry of power, Government of India

7. S.P. Jolhe, M. D. Karalkar, Dr. G. A. Dhomane. 2016. Transmission Options for Standalone system, IEEE sponsored 3rd International Conference on Electronics and Communication Systems (ICECS-2016).

8. S. Sumathi, L. Ashok Kumar, P. Surekha. 2015. Solar PV and Wind Energy Conversion Systems.” Book : Springer International Publishing. 84-94

9. United Nations Foundation. (2012, June). Energy access practitioner network-towards achieving universal energy access by 2030 . 